\title{
The Main Directions of Industry Development in the Period of Digital Transformation for Fuel and Energy Enterprises
}

\author{
Kirill Kolesov \\ Nizhniy Novgorod State Technical University n. a. \\ R. E. Alekseev \\ Nizhniy Novgorod, Russia \\ kikolesov@mail.ru \\ Anna Plekhanova \\ Nizhniy Novgorod State Technical University n. a. \\ R. E. Alekseev \\ Nizhniy Novgorod, Russia
}

\author{
Tatyana Bolonicheva \\ Nizhniy Novgorod State Technical University n. a. \\ R. E. Alekseev \\ Nizhniy Novgorod, Russia \\ Vyacheslav Chalov \\ Nizhniy Novgorod State Technical University n. a. \\ R. E. Alekseev \\ Nizhniy Novgorod, Russia
}

\begin{abstract}
This article reflects the main directions of digital transformation in different types of economic activity, including the fuel and energy complex (nuclear industry). The authors consider the main problems faced by enterprises while transition to digital business conditions. Within the implementation of the government program "Digital economy", at the enterprises of different industries operating teams have been created to analyze the prospects of information development and work out the plans to realize digital transformation. As a result of the authors' analysis, the backlog of Russian business entities in the field of digitalization of their activities has been revealed. Regarding this, it is necessary to pay special attention to finding ways to the interaction between enterprises, the formation of relations between economic entities, the development of partnership between higher education institutions, research institutes and professional communities.
\end{abstract}

Keywords: digital economy, digital transformation, industry, problems of digital transformation for economic activities, scenarios of digital economy development

\section{INTRODUCTION}

In modern reality due to an active implementation of new digital technologies, the transformation of the economy into a digital frame new challenges for the industries' performance and development appeared. Today the industries' digital transformation is based on the Industry 4.0 Program (I4.0). The concept of this program provides the end-to-end digitalization of all processes, combining fundamental technological and organizational changes aimed at significantly improving the performance of companies in different industries thanks to a complete digitization of the information at each stage of value creation. In order to become more competitive, profitable and sustainable on a global scale the companies need to consider new models to generate benefits under the conditions, particularities and operating costs of the new processes applied by Industry 4.0. Although Digital Manufacturing has been applied for years, it has not been recognized as a new technological trend, so, in this context, Digital Manufacturing is presented as an alternative design, and its inclusion in Industry 4.0 is relevant and necessary. [1]

Digital technologies can be applied at every link throughout the value chain, increasing the efficiency of the operation process. Industry 4.0 "summarizes the principles and requirements for the development of industry". It implies a "transition to digital production controlled by intelligent systems in real time and in constant interaction with the external environment", with the prospect of combining things and services into a global industrial network. Operating companies adopt I4.0 merely to sustain their existing business architectures while startup companies radically change their operating models, relying heavily on data analytics and the platform economy [2].

\section{METHODS}

\section{A. Legal Support for the Digital Transformation}

Digital transformation is one of the priorities for the country development; the Digital Economy Program of the Russian Federation has been worked out. The text of the Program was signed by the Government of the Russian Federation on July 28, 2017 (Decree No. 1632-r). This 
document has presented the main goals and key tasks within the framework of several main directions for the further development of the digital economy in Russia until 2025. In the coming years, in accordance with the Program, each branch of the economy will have to change its development directions, taking into account new requirements for the digital transformation.

The most important areas of digital transformation, according to the Program, include:

1. State regulation.

2. Information infrastructure.

3. Research and development.

4. Personnel and education.

5. Information security.

6. Public administration.

7. Smart city program

8. Digital healthcare [3].

Digital transformation results at the intersection of industries appear, using multidisciplinary knowledge about consumers, establishing cross-industry processes, developing digital infrastructure, digital cross-industry platforms and creating new models of the economy on their basis.

The digital transformation of economic activities is carried out by business entities in collaboration with partners involved in value chains, based on the analysis of useful data, the use of digital models and end-to-end processes.

As a megatrend, the so-called Digital Transformation describes the entire potential of new technologies in economy. Thereby new approaches are needed to reveal this potential for the companies. Initial evaluations show the first promising expert feedbacks and possibilities for future research [4].

The digital transformation of industries takes place in the following planes:

- vertical integration of processes within the industry and enterprises;

- horizontal integration of processes and the construction of cross-sectoral, interstate and transnational processes;

- digitalization of products, services, business models and customer access to the ecosystem.

The main trends in cross-industry digital transformation are the interaction of various sectors of the economy, the creation of new business models and end-to-end digital processes in the traditional interfaces of industries, as well as cross-border collaboration.

\section{B. The Program of the Digital Transformation in the Nuclear Industry of the Russian Federation}

Most of the world major companies are currently working out a digital transformation strategy and programs. In the nuclear industry of the Russian Federation, represented by
Rosatom State Corporation, a Unified Digital Strategy, a digital development portfolio and activities for the implementation of the digital transformation program have been developed, which include the following key elements:

- targeted effects of the digitalization for the development of competitive advantages and diversification of Rosatom business (efficiency, adaptability, customer focus, economic effect), conditions and mechanisms for their achievement;

- management system (management architecture, responsible leaders and teams, economists, digitalization analysts, KPIs)

- readiness rating of Rosatom Group Divisions and Organizations for the implementation of digital solutions (incentives and readiness for digital transition: external and internal challenges);

- reassembly of existing digital solutions and the level of their technological readiness (we understand what we can apply from our own developments, and what needs developing and acquiring);

- a priority projects list, motivation and staffing system for the digital transition (PR, training);

- "barriers" and "bottlenecks", systems for their elimination (normative regulation);

- a methodology for assessing the impact of digital investments on business development, involving economic analysis in defining the consequences of digital technologies use.

A comprehensive plan for the development of digital assets of Rosatom State Corporation is aimed at:

- digital diversification of Rosatom business, including the global market;

- increase of the efficiency of Rosatom and the competitiveness of its core business;

- strengthening the role of Rosatom as a system leader in the digitalization of the Russian economy and making Rosatom one of the world leaders in the digital economy.

Russia, through Rosatom, has come to dominate the world reactor export market with a new design, which, it claims, achieves equivalent safety standards to the latest designs from other vendors [5]

One of the priorities of the Unified Digital Strategy of Rosatom is the development, launching the digital products and replication in the industry. From an economic point of view, digital factories represent a chance for relaunching, reengineering of the production and evolving business models for services and products.[6] In 2018 the nuclear industry launched a "product approach" to development, which includes market analysis, product versioning, technical descriptions, testing system, scalable technical support and training system. The concept of a typical organizational structure for the development, market launch and 
TABLE I. IMPACT OF DIGITALIZATION ON ECONOMIC INDICATORS [9]

implementation of digital products has been created. The Digital Products Competency Center has been formed, which is responsible for the development and implementation of "product approach" methods.

In 2018 the following areas of the Program were implemented within the industry: the formation of research competencies and technological groundwork (as a center of competence); the development of methodology and analysis (reports "National Index of Development of the Digital Economy of the Russian Federation" and "Atlas of Crosscutting Technologies of the Digital Economy of Russia"); the development of the Decree of the Government of the Russian Federation establishing the selection procedure and requirements for projects in the field of "end-to-end technologies". [7]

The goals of the digital transformation of Rosatom until 2025 are:

- more than $10 \%$ of revenue comes from a digital product portfolio;

- increased competitiveness of the core business;

- the total economic effect of internal digitalization projects is more than $\$ 1$ billion per year.

The information base of the study is an analysis of integrated reporting of the State Atomic Energy Corporation Rosatom for several years. We conclude that the company is moving towards the digital transformation and creating shared values which are able to encourage its sustainable development in a long run. [8]

\section{RESULTS}

The penetration of digital technologies into key aspects of the life of the Russians and the integration of digital technologies by Russian business is inferior to the EU countries and has a significant growth potential. The main obstacle to the introduction of advanced technologies lies in the field of regulatory and technical support of project activities. The fact is that the codes of practice and regulatory standards developed and adopted in the "digital era" are outdated today and require either updating or replacement with fundamentally new documents. In addition, there is a problem of the mandatory and optional application of existing codes of practice. There are two normative lists of these sets of rules - those that are mandatory for use, and those that are only recommended.

Evidently, the digital sector continues to account for less than 10 percent of the economies in most countries, judging by value added, income, or employment. Digitalization has penetrated many areas of activity, and indeed almost the entire economy can be included in the "digital economy" in a broad sense. However, it is more realistic to focus efforts on measuring a specific range of economic activities underlying digitalization.

According to the study by McKinsey \& Company digital technologies significantly improves economic indicators.

\begin{tabular}{|c|c|c|c|c|}
\hline & \multirow{2}{*}{$\begin{array}{c}\text { Percentage of } \\
\text { revenues } \\
\text { invested in } \\
\text { the } \\
\text { digitalization, } \\
\%\end{array}$} & \multirow[b]{2}{*}{$\begin{array}{c}\text { Return on } \\
\text { investment } \\
\text { (ROI), \% }\end{array}$} & \multicolumn{2}{|c|}{$\begin{array}{c}\text { Economic growth (average } \\
\text { for } 3 \text { years), } \%\end{array}$} \\
\hline & & & $\begin{array}{l}\text { Average } \\
\text { revenue }\end{array}$ & $\begin{array}{c}\text { Earnings } \\
\text { before } \\
\text { interest and } \\
\text { taxes (EBIT) }\end{array}$ \\
\hline $\begin{array}{l}\text { Active } \\
\text { investor }\end{array}$ & 24 & 14 & 12 & 10 \\
\hline $\begin{array}{l}\text { Other } \\
\text { companies }\end{array}$ & 5 & 6 & 6 & 6 \\
\hline
\end{tabular}

Actively investing in digitalization companies show significantly better financial results. Digitalization of the Russian economy is a source of long-term economic growth. The contribution of the digital economy to the Russian economy is estimated at $5.1 \%$ of Gross Domestic Product (GDP) for 2018 [10].

Measuring the value added generated by information and communication technology (ICT) industries only provides a partial view of the importance of ICT to a country's economy. In addition to final ICT products, the output from domestic ICT industries is also embodied (via intermediate products) in a wide range of goods and services meeting final demand (business capital investment, household and government consumption), both domestically and abroad. Similarly, the output from domestic non-ICT industries is present in many ICT goods and services consumed worldwide through domestic interconnections and participation in global value chains (GVCs). Global demand for ICT goods and services through international trade and investment can drive the activities of many upstream domestic non-ICT industries. Combining the value added generated by domestic ICT industries with the domestic non-ICT industry value added embodied in global demand for ICT goods and services could be a first step towards defining an extended ICT footprint, or "ICT-EF". In 2011, the United States, Japan and China together accounted for about $45 \%$ of the world's extended ICT footprint. The European Union as a whole accounted for $23 \%$, a share only marginally higher than that of the United States. Neglecting the value added generated in other sectors of the economy to meet global demand for ICT final goods and services can result in under-estimation of the role played by the "digital" economy [11]. The following table shows the dynamics of the spread of internal information systems and shared access to information within the organization.

\section{DISCUSSION}

Considering the diversity of ideas about the digital transformation, there is a fairly wide range of studies devoted to various issues related to the barriers and challenges of the digital transformation, its strategies, elements, etc. This predetermines various approaches to the definition of the concept and essence of the digital transformation. This study contributes to the body of knowledge associated with digital transformation processes and provides the basis for further research in this area. 
TABLE II. INTEGRATION OF INTERNAL INFORMATION SYSTEMS AND SHARED ACCESS TO INFORMATION WITHIN THE ORGANIZATION [12]

\begin{tabular}{|l|l|l|l|l|l|l|l|}
\hline Indicator & $\mathbf{2 0 1 2}$ & $\mathbf{2 0 1 3}$ & $\mathbf{2 0 1 4}$ & $\mathbf{2 0 1 5}$ & $\mathbf{2 0 1 6}$ & $\mathbf{2 0 1 7}$ & $\mathbf{2 0 1 8}$ \\
\hline $\begin{array}{l}\text { Percentage of organizations that had special software tools for managing } \\
\text { purchases of goods (works, services) in the total number of surveyed } \\
\text { organizations, \% }\end{array}$ & 36,2 & 38,6 & 36,3 & 38,4 & 37,8 & 36,2 & 38,3 \\
\hline $\begin{array}{l}\text { Percentage of organizations that had special software tools for managing } \\
\text { sales of goods (works, services) in the total number of surveyed } \\
\text { organizations, } \%\end{array}$ & 22,8 & 22,9 & 20,3 & 21,9 & 21,8 & 22,0 & 25,9 \\
\hline $\begin{array}{l}\text { Percentage of organizations that used ERP (enterprise resource planning) } \\
\text { systems in the total number of organizations surveyed, \% }\end{array}$ & 6,5 & 7,5 & 10,1 & 9,3 & 10,7 & 12,2 & 13,8 \\
\hline $\begin{array}{l}\text { Percentage of organizations that used CRM } \\
\text { customer relationship management) systems in the total number of } \\
\text { organizations surveyed, \% }\end{array}$ & 5,0 & 5,7 & 7,2 & 9,9 & 9,4 & 10,3 & 13,2 \\
\hline $\begin{array}{l}\text { Percentage of organizations that used electronic document management } \\
\text { systems in the total number of organizations surveyed, \% }\end{array}$ & 60,4 & 61,7 & 58,9 & 62,7 & 66,1 & 66,1 & 68,6 \\
\hline
\end{tabular}

Today, digital transformation is a buzzword in the academic and business environment. The elements of the digital transformation, drivers and barriers, value creation through digital transformation - these and other related topics have been often discussed in recent years. In 2017, the Organization for Economic Co-operation and Development (OECD) launched a new global project, "Transition to Digital: Transforming for Growth and Wealth." Its goal is to help policymakers better understand the ongoing digital transformation and create an environment that allows their economies and societies to flourish in a world that is becoming increasingly digital and data driven.

Why is so much attention focused on the digital transformation? First, digitalization is an integral part of the society progress, the economy and business. Digitalization and globalization - these processes determine the current existence of the countries' economies, regions, industries and companies. According to the forecast of the European Commission, the "transformational industrial and technological revolution" will become one of the key global trends until 2030.

In the digital transformation strategy of companies in various industries short cycles should be highlighted, where it is recommended to work out programs for the digital development, monitor and update them at the end of the cycle. It is necessary to create competence centers for the key end-toend digital technologies.

The Autonomous Non-Profit Organization (ANO) Digital Economy, created to support projects and initiatives in the field of the digital transformation, focuses on end-to-end digital technologies. In its basic form, the program "Digital Economy of the Russian Federation" does not take into account the specific character of industries. The structure of industries and even sub-sectors vary greatly. The solutions needed for the rapid development of each industry are different. ANO "Digital Economy" may take on a coordinating function. For example, the program "Digital Economy of the Russian Federation" implies a creation of a unified information infrastructure for all industries.

The essence of the digital transformation is changing business processes based on digital technologies. However, digital transformation does not automatically increase the efficiency of processes and competitiveness of the company. Therefore, like any mechanisms for the development of a company, it is crucial not only to consider digital transformation as a timely necessity, but also evaluate its effectiveness. To do this, you can use a set of economic criteria - reducing time and cost of performing processes, increasing the operational readiness of facilities, the emergence of new economic opportunities. You can also consider digital transformation as an investment project or a program consisting of several projects. In this case, the criteria of net present value, payback period, profitability index are used.

One of the tasks of the digital transformation of industries is to create an ecosystem of the digital economy as a partnership of organizations in various industries or subsectors, ensuring constant interaction of their technology platforms, services, analytical and information systems. Collaboration and cooperation of companies within the industry, as well as cross-industry interaction, can lead to increased efficiency and innovation activity.

\section{CONCLUSION}

The digital foundations for the development of the digital economy in Russia have been formed satisfactorily. The development of individual digital platforms, the use of digital technologies and e-Commerce is at a good level. At the same time, the digital transformation of the public sector (public administration, education, health, culture) and, especially, the transformation of business under the influence of digital technologies is lagging far behind. Industry and transport lag behind EU countries in terms of digitalization.

The nuclear industry could be a powerful driver of digital transformation, scientific and technological progress, a stimulating mechanism for the development of a wide range of industrial and technological segments of the national economy. [13]. The companies of the fuel and energy complex (nuclear industry) are characterized by the requirements to ensure energy security, taking into account the entire life cycle of the construction and operation of nuclear power plants, regular training, updating knowledge and competencies of employees; the duration of competeies throughout the life cycle for the construction of complex engineering facilities, 
[5] S. Thomas, "Russia's Nuclear Export Programme", Energy Policy, t. 121, pp. 236-247, October 2018.

determines the importance of maintaining critical knowledge and the need for a sustainable innovative development [14]. These reasons force to intensify the search for the ways of interaction, the formation of relations between enterprises, partnership between universities, research institutes, professional communities.

As a result, this concept should be embedded in the strategies of corporations of various types of economic activity and requires the development of new models, platforms, systems, and technologies, so the companies of different market sectors where added value is created with digital technologies are becoming the sources of the economic growth [15].

The potential effect on GDP from the digitalization of the economy by 2025 is estimated at 4.1-8.9 trillion rubles, which will amount to $19-34 \%$ of the total increase in GDP.

\section{References}

[1] J.C. Suarez, F.F. Salazar, I.F. Nava, and R.H. Hernandez, "Industry 4.0 and Digital Manufacturing: a Design Method Applying Reverse Engineering", Ingenieria, t. 24, no. 1, pp. 6-28, Jan-Apr 2019.

[2] G.J. Hahn, "Industry 4.0: a supply chain innovation perspective", International Journal of Production Research, p. 17.

[3] Digital economy of the Russian Federation [Electronic resource]. Available http://static.government.ru/media/files/9gFM4FHj4PsB79I5v7yLVuPg u4bvR7M0.pdf.

[4] T. Greff, C. Neu, and D. Johann, "Digitization Driven Design - A Guideline to Initialize Digital Business Model Creation", 8th International Symposium on Business Modeling and Software Design, BMSD, Vienna. t. 319. pp. 308-318, 2-4 July 2018.
[6] M. Nedelcu, A. Dima, and R. Dinulescu, "Digital factory - a prerequisite for revitalizing the production sector", 12th International Management Conference on Management Perspectives in the Digital Era, IMC, Bucharest Univ Econ Studies F. M. A. S. E. B., Bucharest Univ. Econ. Studies. B. R.: International Management Conference, Bucharest, Romania: Editura Ase, pp. 520-529, 2018.

[7] Rosatom group annual report [Electronic resource]. Available at: https://www.rosatom.ru/upload/iblock/fa7/fa759a96c90510116b0b0632 519522cb.pdf.

[8] V. Yevgeniya and N.A. Redchikova, "Business Models of Companies: From Profit to Sustainable Development and Value Creation", Upravlenets, t. 9, no. 4, pp. 9-19, 2018.

[9] Cross-industry survey worldwide by McKinsey \& Company [Electronic resource]. Available at: http://d-russia.ru/wpcontent/uploads/2018/10/

20181025_tsifrovoe-budischee-makkinzi.pdf.

[10] Russian Association of electronic communications [Electronic resource]. Available at: https://raec.ru.

[11] OECD, Inter-Country Input-Output, ICIO Database [Electronic resource]. Available at: http://oe.cd/icio.

[12] "Monitoring the development of the information society in the Russian Federation", Rosstat [Electronic resource]. Available at: http://www.gks.ru/free_doc/new_site/business/it/monitor_rf.xls.

[13] Y.A. Olenin and V.I. Il'gisonis, "Challenging Scientific and Technical Problems of Nuclear Power", Herald of the Russian Academy of Sciences, t. 89, no. 2, pp. 105-111, March 2019.

[14] A. Zutshi and A. Grilo, "The Emergence of Digital Platforms: A Conceptual Platform Architecture and impact on Industrial Engineering", Computers \& Industrial Engineering, t. 136, pp. 546-555, October 2019.

[15] N. Minin and T. Vlcek, "Determinants and considerations of Rosatom's external strategy", Energy Strategy Reviews, t. 17, pp. 37-44, September 2017. 